\title{
Isolate two Crustaceans which infect Cyprinus carpio L. from Bab Al-Muatham fish markets, Baghdad City
}

\author{
Nahla Talib Mansoor* \\ Sadiq M. Jawad Al-Shaikh** \\ * Ministry of Science and Technology ** College of Medicine Baghdad University
}

\begin{abstract}
s
During the period from November 2007 till October 2008, a total of 255 specimens of the cyprinid fish, from freshwater fish Cyprinus carpio Linnaeus, 1758, were collected from fish markets east of Baghdad city. Microscopic examination of these fishes revealed that they were infected with two species of the crustaceans [Argulus foliaceus (0.8\%) and Ergasilus sieboldi (20\%)].The present study included the following: The clinical signs which were caused by the crustaceans, which included redness and an opacity of the skin, increase of mucus secretion and rapid movements of the operculum. The percentage incidence of the infection with these parasites were also found to be related to different length groups of the host, the larger fishes were more infected $(95.2 \%)$ while the smaller fishes were less infected $(0.8 \%)$.
\end{abstract}

Key words: crustaceans, cyprinus carpioL.fish.

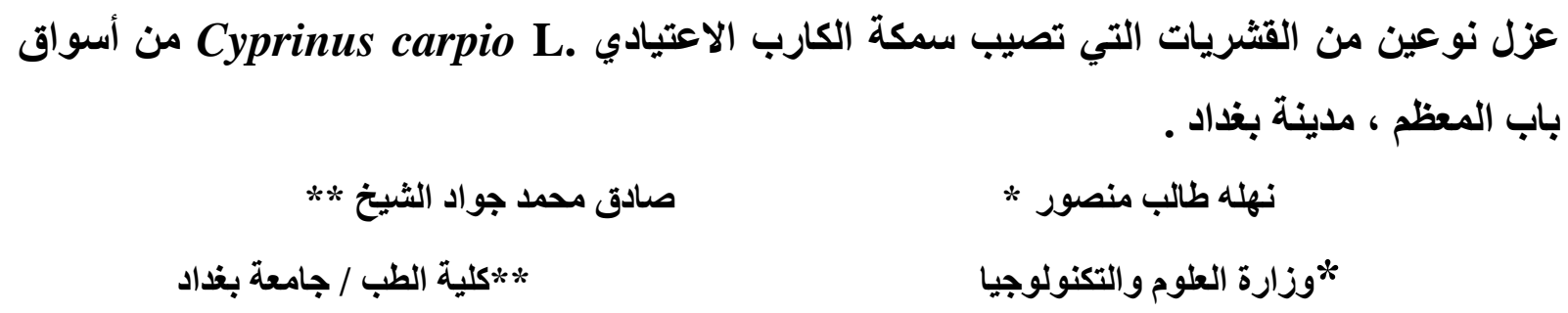

\section{الخلاصة}

أثناء المدة المحصورة بين تشرين الثناني 2007 وتثرين الأول 2008 جمعت وفحصت 255 سمكة تعود إلى عائلة الثبوطيات، من أسماك المياه العذبة وهي سمكة الكارب الإعتيادي Cyprinus carpio، جمعت الأسماك من أسواق بيع

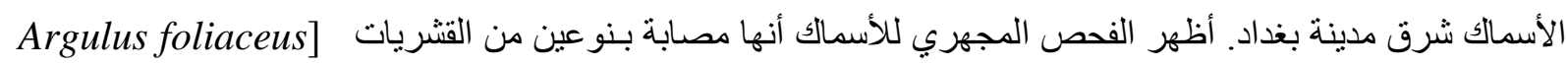
(20.8\%) Ergasilus sieboldi (20)]. تضمنت الدراسة الحالية الجوانب الآتية : دراسة العلامات السريرية التي تسبيها القشريات و التي تمثلت باحمرار و عتامة الجلد وزيادة إفراز المخاط وسرعة الحركات التنفسية. هناك علاقة بين

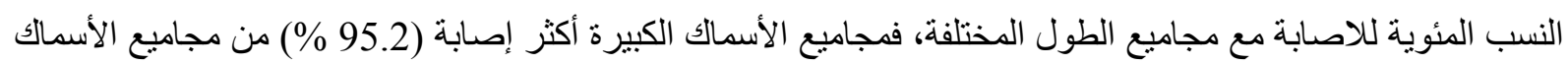

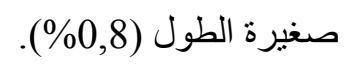

\section{Introduction}

Fish culture is an old branch of animal's husbandry (1). Fishes are considered as a resource of protein, fat, phosphate, Iron, calcium, amino acids and vitamins which are soluble in water and other vitamins which are soluble in fat (2). Common carp Cyprinus carpio L. 


\section{The Iraqi Journal of Veterinary Medicine; 35 ( 1 ): 52 - 59: 2011}

was introduced for the first time to Iraqi water in 1954 (3) in Al-Zaafaraniya fish farm. All living beings can be in certain circumstances subjected to diseases, and fishes make no exception (4). These diseases are divided into two types: infectious and non-infectious diseases (5). Non infectious diseases are caused by abiotic factors. These diseases are called environmental diseases. Infectious diseases are caused by biotic factors such as bacteria, fungi, viruses and parasites. Parasites cause a decrease in fish resistance to other diseases and can be exposed to secondary infections like bacterial and fungal diseases (6;7). Crustacean parasites, which may become problematic under intensive aquaculture conditions such as overcrowded conditions, may become particularly lethal to juvenile fishes (5).

\section{Materials and Methods}

A total of 255 fishes were collected from Bab Al-Muatham fish markets, east of Baghdad city, during the period from November 2007 till October 2008. Five to seven fishes were collected weekly. These samples were transferred alive or freshly dead to the research laboratory by plastic containers. Fishes were examined as soon as possible after killing them by pithing method. Total and standard length were taken and fishes were weighted by balance type Mettler PE 3600gm. The range and (mean) of total length was $16-41(27.5 \mathrm{~cm})$. The range and (mean) of weight was 62-1300 (342.8gm). The external surface of the fishes: fins, skin and gills were examined under a magnifying lens (x10), then scrapping of the skin was done by spatula to collect the mucus in Petri dish with normal saline $(0.9 \%)$ for microscopic examination. Next, the gills were removed from the branchial cavity and placed in Petri dish for microscopic examination under the compound microscope type Novex (Holland), under a power of 100-400 times. The parasites were identified according to the following references of $8,9,10$ and 11 . The parasites were photographed by Olympus microphotographic system with a camera. After diagnosing of the parasites, they were fixed by $10 \%$ formalin and staining by aceto-carmine. This stain preparation was carried on according to (12 and 13) as in the following form:

$\begin{array}{lc}\text { Carmine } & 0.5 \mathrm{gm} \\ 45 \% \text { glacial acetic acid } & 45 \mathrm{gm} \\ \text { Distalled water } & 50 \mathrm{ml}\end{array}$

The prevalence of infection was calculated as demonstrated by (14).

Prevalence $(\%)=\quad \frac{\text { Number of infested fishes }}{\text { Total number of fishes examined }} \times 100$


The Iraqi Journal of Veterinary Medicine; 35 ( 1 ): 52 - 59: 2011

Statistical Analysis Chi square test was applied to determine the significancy in the percentage incidence of infection of parasite species with different fish length groups.

\section{Results}

The result of the external examination of these fishes demonstrated that 53 fishes (out of 255 examined fishes) were infected with two crustacean parasites (Argulus foliaceus $(0.8 \%)$ and Ergasilus sieboldi (20\%) figure (1) as shown in table (1). So, the overall prevalence of infection was $20.7 \%$ as shown in table (2). The skin of infected fishes showed hemorrhagic foci with increase of mucous secretion. In some areas, presence of bluish-white areas on the skin was noticed. Also, redness a round areas on the base of fins were noticed. Gills of infected fishes presented hyperemic areas with increase in mucous secretion. Table (2) shows percentage incidence of different length groups of $C$. carpio with these two species of crustaceans. Chi-square test shows significant differences in the infection with these parasites. Statistical analysis (Chi-square test) demonstrated significant differences between percentage incidence of infection and different length groups of $C$. carpio. The maximum percentage incidence of parasites $(95.2 \%)$ was recorded from larger length group $(>35 \mathrm{~cm})$ in comparison with the two other groups.

Phylum Arthropoda

Class Crustacea

Order Copepoda

Family Ergasilidae

Genus Ergasilus

Species Ergasilus sieboldi Nordmann, 1832

Order Branchiura

Family Argulidae

Genus Argulus

Species Argulus foliaceus (L., 1758) 
The Iraqi Journal of Veterinary Medicine; 35 ( 1 ): 52 - 59: 2011

Table (1): Diagram showing classification of the parasites of $C$. carpio of the present study.

\begin{tabular}{|c|c|c|c|}
\hline \multicolumn{4}{|c|}{ A-Argulus foliaceus } \\
\hline $\begin{array}{r}\text { Fish length groups } \\
(\mathrm{cm})\end{array}$ & $\begin{array}{r}\text { Number of fish } \\
\text { examined }\end{array}$ & $\begin{array}{rr}\text { Number of fish } \\
\text { infected }\end{array}$ & $\begin{array}{r}\text { Percentage } \\
\text { incidence }(\%)\end{array}$ \\
\hline $16-25$ & 124 & 0 & 0 \\
\hline $26-35$ & 110 & 0 & 0 \\
\hline$>35$ & 21 & 2 & 9.5 \\
\hline Total & 255 & 2 & 0.8 \\
\hline & & & $\begin{array}{l}\text { Calculated } \\
\text { Tabulated }\end{array}$ \\
\hline
\end{tabular}

Table (2): Percentage incidence of different length groups of $C$. carpio with two species of crustaceans.

\section{B - Ergasilus sieboldi}

\begin{tabular}{|r|rr|rr|r|}
\hline $\begin{array}{r}\text { Fish length groups } \\
(\mathrm{cm})\end{array}$ & $\begin{array}{r}\text { Number of fish } \\
\text { examined }\end{array}$ & $\begin{array}{r}\text { Number } \\
\text { of fish } \\
\text { infected }\end{array}$ & $\begin{array}{r}\text { Percentage } \\
\text { incidence }(\%)\end{array}$ \\
\hline $16-25$ & 124 & 1 & 0.8 \\
\hline $26-35$ & 110 & 30 & 27.3 \\
\hline$>35$ & 21 & 20 & 95.2 \\
\hline Total & 255 & 51 & 20 \\
\hline
\end{tabular}

Calculated $\chi^{2}=44.93$

Tabulated $\chi^{2}=5.99$

$\mathrm{P} \leq 0.01$

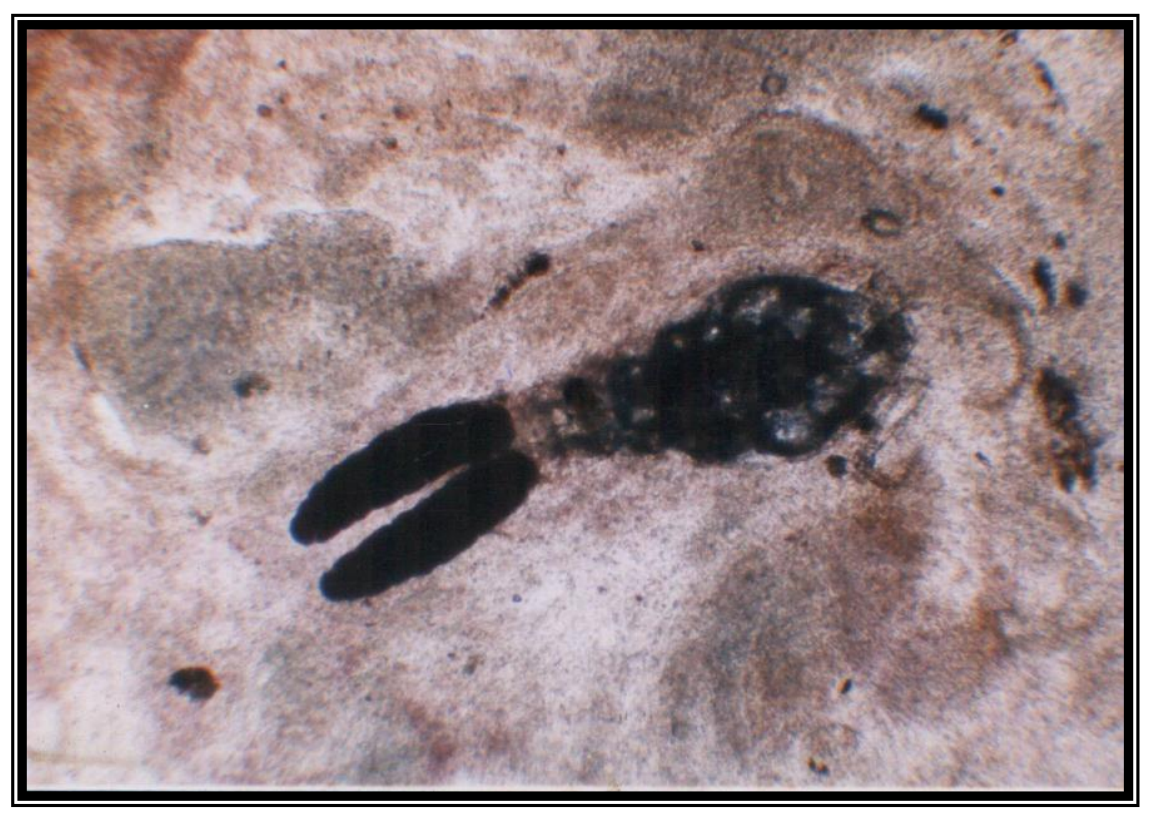

Figure (1): Ergasilus sieboldi in the gills of C. carpio (x100). 


\section{The Iraqi Journal of Veterinary Medicine; 35 ( 1 ): 52 - 59: 2011}

\section{Discussion}

The results of the present study demonstrated that the common carps were infected with two species of crustasean parasites:

\section{Argulus foliaceus}

This parasite was recorded for the first time in Iraq from skin of B. luteus and C. carpio from different localities of Iraq (15). Afterwards, it was recorded from ten other species of freshwater fishes (16) like C. carpio in some fish farms like Al-Zaafaraniya fish farm (17), Al-Furat fish farm (18) as well as from fish farms in north of Baghdad city (19), fish farms in Neinava province (20) and Ainkawa fish hatchery in Erbil city (21). Also, it was recorded from natural waters like Al-Qadisiya dam lake (22) and Tigris river at Salah Al-Deen province (23).

\section{Ergasilus sieboldi}

This parasite was recorded for the first time in Iraq from gills of Aspius vorax from different fish markets in Iraq (15). Afterwards, it was recorded from 16 species of freshwater fishes like C. carpio from Al-Latifiya and Al-Suwairai fish farms (24), Al-Furat fish farm (18; 25), Al-Amiriya fish farm (26) and Al-Zaafaraniya fish farm (27). Also, it was recorded from natural waters like Al-Qadisiya dam lake (22) and Al-Husainia creek in Karbala province (28).

The crustaseans of fishes cause clinical signs that observed on the infected fishes, fishes become dull and feeble, rest frequently near the surface of the water, while every movement becomes more difficult and the animals die from complete exhaustion (1). The fins are held close to the body. Skin becomes slimy than normal with the appearance of small blood spots. The gills are expanded and become very pale. These signs agree with those of (4, 5 and 7). These clinical signs appear due to necrosis that occurs in the places of parasite attachment, increase secretion of the mucus in the site of infection and deformation of the epithelial cells of gill lamellae (1and 5). The fluctuation of prevalence of parasites in different length groups of $C$. carpio of the present study demonstrated that the highest prevalence of parasites (95.2\%) was recorded from fish samples belonging to the larger length group $(>35 \mathrm{~cm})$ and the lowest $(0.8 \%)$ was recorded from fish samples belonging to the smaller length group (16$25 \mathrm{~cm})$. So, higher infection was recorded from fishes of the larger length group more than the smaller and medium length groups, due to the increase of the surface area of the infected fishes exposed to parasites. The present finding agrees with those of (18, 26 and 28).

\section{References}

1-Amlacher E (1970). Textbook of fish diseases (Engl. Transl.). TFH Publ. Jerseycity: pp302. 


\section{The Iraqi Journal of Veterinary Medicine; 35 ( 1 ): 52 - 59: 2011}

2- Zatev FA Cazevater AF Macrova TA Monther L Basevalov FN and Lankov LN (1986). Technology of fish products. Translated by Hindi MJ Basrah Univ Press: pp853. (In Arabic).

3- Al-Hamed MI (1960). Carp culture in Iraq. Iraqi J Agric Res. 1(2): 14-23.

4- Duijn Van C Jnr (1973). Diseases of fishes $3^{\text {rd }}$ edn. Iliffe Books London. pp372.

5- Roberts RJ (1978). Fish pathology. Bailliere Tindal London: pp318.

6-Olsen OW (1974). Animal parasites Their life cycles and ecology, $3^{\text {rd }}$ edn., Univ Park Press Baltimore. pp562.

7- Johnsen BO (1978). The effect of an attack by the parasite Gyrodactylus salaries on the population of salmon parr in the river Lakselva Misvaer in northern Norway. J Fish Biol. 11: 7-9.

8- Yamaguti S (1958). Systema Helminthum, vol. I: The digenetic trematodes of vertebrates. Intersci Publ New York. pp1275.

9- Yamaguti S (1963). System Helminthum, vol. IV: Monogenea and Aspidocotylea. Inersci Publ NewYork. pp699.

10- Bykhovskaya-Pavlovskaya IE Gusev AV Dubinia MN Izyumova NA Smirnova TS Sokolovskaya Shtein GA Shul'man SS and Epshtein VM (1962). Key to parasites of freshwater fish of the USSR Akad. Nauk SSSR Moscow. pp727. (In Russian).

11-Gussev AV (1985). Parasitic metazoans: class Monogenea. In: Bauer ON (Ed.). Key to the parasites of freshwater fish fauna of the USSR Nauka Leningrad 2: 1-424. (In Russian).

12- Carleton HM (1967). Histological technique, $4^{\text {th }}$ edn., Oxford Univ Press New York. pp 432.

13- Al-Khateeb EI and Al-Khateeb KAR (1988). Histological technique. Al-Watania Libraries Amman. pp126. (In Arabic).

14-Margolis L Esch GW Holmes JC Kuris AM and Schad GA (1982). The use of ecological terms in parasitology (Report of an ad hoc committee of the American Society of Parasitologists). J Parasitol 68(2): 131-133.

15-Herzog PH (1969). Untersuchungen über die parasiten der sübwasserfische des Irak Arch Fischereiwiss 20(2/3) 132-147.

16- Mhaisen FT (2009). Index- catalogue of parasites and disease agents of fishes of Iraq. (Unpubl.). 


\section{The Iraqi Journal of Veterinary Medicine; 35 ( 1 ): 52 - 59: 2011}

17- Ali MD and Hussien JH (1986). Field and laboratory observations on the lice Argulus foliaceus and their treatment on fish. Eighth Sci Conf Iraq Vet Med Assoc Baghdad: 18-20 Feb. 1986: 46-47. (Abstract).

18-Al-Zubaidy AB (1998). Studies on the parasitic fauna of carps in Al-Furat fish farm Babylon province Iraq. Ph D Thesis Coll Sci Univ Babylon. pp141.

19- Khalifa KA (1989). Incidence of parasitic infestation of fishes in Iraq. Pak Vet J. 9(2): 66-69.

20- Al-Hamdane AH and Hussan AA (2002). Study of some parasitic diseases of pond fish in Mosul area. Iraqi J Vet Sci. 15(1): 1-5.

21- Al-Marjan KSN (2007). Some ectoparasites of common carp (Cyprinus carpio) with experimental study of the life cycle of the anchor worm (Lernaea cyprinacea) in Ainkawa fish hatchery Erbil province. M Sc Thesis Sci Educ Coll Univ Salahaddin. pp76.

22- Asmar KR Balasem AN Mhaisen FT Al-Khateeb GH and Al-Jawda JM (1999). Survey of the parasites of some fish species from Al-Qadisiya dam lake Iraq Ibn AlHaitham J Pure Appl Sci. 12(1). 52-61.

23- Al-Jawda JM Balasem AN Mhaisen FT and Al-Khateeb GH (2000). Parasitic fauna of fishes from Tigris river at Salah Al-Deen province Iraq. Iraqi J Biol Sci.19 and 20. $16-24$.

24-Ali NM Abul-Eis ES and Abdul-Ameer KN (1988a). Study on the parasites of common carp Cyprinus carpio and other freshwater fishes in Habbaniyah lake, Iraq J Biol Sci Res. 19(2). 395-407.

25-Al-Jadoaa NAA (2002). The parasitic infections and pathological changes of some local and cultured fishes from Al-Qadisiya and Babylon provinces. PhD Thesis Coll EducUniv Al-Qadisiya. pp158.

26-Al-Nasiri FS (2000). Parasitic infections of fishes in a man-made lake at Al-Amiriya region Baghdad MSc Thesis Coll Educ (Ibn Al-Haitham) Univ Baghdad. pp133.

27- Mohammad-Ali NR Balasem AN Mhaisen FT Salih AM and Waheed IK (1999). Observation on the parasitic fauna in Al-Zaafaraniya fish farm south of Baghdad Vet. 9(2): 79-88.

28-Al-Saadi AAJJ (2007). Ecology and taxonomy of parasites of some fishes and biology of Liza abu from Al-Husainia creek in Karbala province Iraq. PhD Thesis Coll Educ (Ibn Al-Haitham) Univ Bahghdad. pp155. 